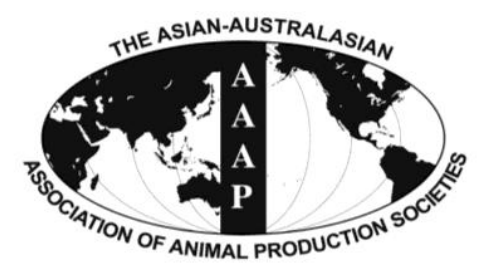

Asian-Aust. J. Anim. Sci.

Vol. 25, No. 2 : 256 - 260

February 2012

www.ajas.info

http://dx.doi.org/10.5713/ajas.2011.11217

\title{
Immune Response of Broiler Chickens Fed Diets Supplemented with Different Level of Chromium Methionine under Heat Stress Conditions
}

\author{
S. K. Ebrahimzadeh*, P. Farhoomand and K. Noori \\ Department of Animal Science, College of Agriculture, University of Urmia, Iran
}

\begin{abstract}
The objectives of this study were to investigate the immune responses of broiler chickens fed diets supplemented with different level of chromium methionine (CrMet) in heat stress (HS) condition. Two hundred and eighty eight male broiler chickens (Ross 308) were allocated to four treatment groups (supplementation with 0, 200, 400 or $800 \mathrm{ppb} \mathrm{Cr}$ in the form of CrMet) in a completely randomized design. The experiment was conducted at heat stressed condition and all birds were kept under temperature of $33 \pm 2{ }^{\circ} \mathrm{C}$. Antibody titers against Newcastle disease virus (NDV) and infectious bronchitis virus (IBV), heterophil to lymphocyte ratios (H/L), and concentration of plasma cortisol (CPC) were measured at 21 and $42 \mathrm{~d}$. At 42 days of age two birds were chosen randomly from each replicate, slaughtered, spleen and bursa of Fabricius were collected, weighed and expressed as a percentage of live body weight. Antibody titers against NDV and IBV at 21 and 42 days of age in broiler fed supplemental CrMet were higher than in broiler chickens fed control diet $(p<0.05)$. CPC level in broiler chickens fed CrMet were significantly $(p<0.05)$ decreased. Increases in lymphocyte counts and consequently a decrease in heterophil to lymphocyte ratios in broiler chickens fed $800 \mathrm{ppb} \mathrm{Cr}$ were observed at 21 and $42 \mathrm{~d}$. Supplementation with CrMet had no significant effect on lymphoid organs of broilers. The results suggest that dietary CrMet supplementation at a level of $800 \mathrm{ppb}$ can improve some immune responses of broiler chickens under heat stress conditions. (Key Words : Broiler, Chromium Methionine, Immune Response, Heat Stress)
\end{abstract}

\section{INTRODUCTION}

Heat stress (HS) is of great concern in the poultry industry. Feed efficiency, growth rate, mortality, and other important traits governing productivity in the poultry industry are adversely affected by severe HS. It has been established that high environmental temperatures affect the development of a specific immune response in chickens (Thaxton et al., 1968; Thaxton and Siegel, 1972). Chromium is a component of glucose tolerance factor (GTF) and is important in carbohydrate, fat, and protein metabolism presumably by potentiating the action of insulin (Anderson, 1987; Mertz, 1993). Stress and disease increased urinary excretion of $\mathrm{Cr}$ (Pekarek et al., 1975; Borel et al., 1984; Anderson et al., 1988) and may exacerbate a marginal $\mathrm{Cr}$ deficiency. Chromium supplementation has shown be effective in diminishing adverse effects of stress, reducing cortisol levels and improving immunity (Chang and Mowat, 1992; Kegley and

\footnotetext{
*Corresponding Author: S. K. Ebrahimzadeh. Tel: +989144469 873, Fax: +984436223770, E-mail: ebrahimzadeh87@gmail.com Received May 5, 2011; Accepted September 26, 2011
}

Spears, 1995). Frequently these factors become important in enhanced growth performance (Moonsie-Shageer and Mowat, 1993). Improvements in immune response have been observed when organic forms of $\mathrm{Cr}$ were supplemented to broilers (Luo et al., 1999), stressed feeder calves (Chang and Mowat, 1992; Moonsie-Shageer and Mowat, 1993) and dairy cows (Burton et al., 1993). No recommendations for $\mathrm{Cr}$ are currently listed for poultry (NRC, 1994, 1997) and most poultry diets are basically composed of plant origin ingredients, which have usually a low content of $\mathrm{Cr}$ (Giri et al., 1990). Chromium-Lmethionine is a newly available organic chromium source whose bioavailability and effects have not been previously determined in broiler chickens. This study was conducted to investigate the effects of different levels of $\mathrm{Cr}$ methionine on immune responses in heat-stressed broiler chickens.

\section{MATERIALS AND METHODS}

Two hundreds and eighty eight one-day-old male broiler chickens (Ross 308) were allocated to four treatments in a completely randomized design. Dietary treatments supplemented with 0 (control), 200, 400 and $800 \mathrm{ppb} \mathrm{Cr}$ in 
the form of $\mathrm{Cr}$ - methionine (contain 1,000 $\mathrm{mg} \mathrm{Cr} \mathrm{kg}^{-1}$ ). Each dietary treatment was randomly allocated to six replicates of 12 chicks each. Chicks were raised from 1 to 42 days of age, in controlled house with mean value of daily temperature $33 \pm 2{ }^{\circ} \mathrm{C}$. The chickens were fed a maizesoybean meal starter diet ( $219 \mathrm{~g}$ protein, 3,050 kcal ME kg${ }^{-1}$ ) up to 21 days and a finisher diet $(200 \mathrm{~g}$ protein, 3,200 kcal ME $\mathrm{kg}^{-1}$ ) up to 42 days. The basal diets in mash form were formulated to meet or exceed the nutrient requirements of broiler chickens (NRC, 1994). Cr contents were 3.39 and $3.85 \mathrm{ppm}$ in starting and finishing basal diets, respectively, as measured by atomic absorption spectrometer with a graphite furnace (Perkin-Elmer, AAnalyst 600, USA). The diets and fresh water were provided ad libitum. Ingredients and chemical composition of the starter and finisher basal diets are shown in Table 1.

Live infectious bronchitis disease vaccine (H120) was administered orally (drinking water) at 4 and $13 \mathrm{~d}$. All chicks were intramuscularly immunized with killed vaccine of Newcastle viruses at age of 9 days.

On days 21 and 42 blood samples were collected from the wing vein of two birds per replicate (using EDTA as anticoagulant). Samples were centrifuged at 3,500 $\mathrm{g}$ for 15

Table 1. Ingredients and chemical composition of the starter and finisher basal diets

\begin{tabular}{|c|c|c|}
\hline Ingredients (\%) & Starter & Finisher \\
\hline Corn & 52.09 & 57.43 \\
\hline Soybean meal (CP 44\%) & 39.4 & 33.97 \\
\hline Soybean oil & 4.8 & 5.6 \\
\hline Dicalcium phosphate & 1.6 & 1.21 \\
\hline Oyester shell & 1.08 & 0.92 \\
\hline Salt & 0.4 & 0.32 \\
\hline Vitamin premix $^{1}$ & 0.25 & 0.25 \\
\hline Mineral premix ${ }^{2}$ & 0.25 & 0.25 \\
\hline DL-methionine & 0.13 & 0.06 \\
\hline \multicolumn{3}{|l|}{ Calculated composition } \\
\hline Metabolizable energy (Kcal/kg) & 3,050 & 3,200 \\
\hline Crude protein $(\%)$ & 21.92 & 20 \\
\hline Calcium (\%) & 0.98 & 0.95 \\
\hline Available phosphorus (\%) & 0.43 & 0.35 \\
\hline Methionine+cystine (\%) & 1.01 & 0.78 \\
\hline Lysine (\%) & 1.27 & 1.13 \\
\hline Chromium analyzed (ppm) & 3.39 & 3.85 \\
\hline \multicolumn{3}{|c|}{$\begin{array}{l}{ }^{1} \text { Vitamin premix contains followings in } 2.5 \mathrm{~kg} \text { : vitamin } \mathrm{A}, 9,000,000 \mathrm{IU} \text {; } \\
\text { vitamin } \mathrm{D}_{3}, 2,000,000 \mathrm{IU} \text {; vitamin E, } 3,600 \mathrm{mg} \text {; Vitamin } \mathrm{K}_{3}, 2,000 \mathrm{mg} \text {; } \\
\text { thiamine } 1,750 \mathrm{mg} \text {; riboflavin, } 6,600 \mathrm{mg} \text {; panthothenic acid, 9,800 } \\
\mathrm{mg} \text {; vitamin } \mathrm{B}_{6}, 2,940 \mathrm{mg} \text {; vitamin } \mathrm{B}_{12}, 15 \mathrm{mg} \text {; niacin, } 29,700 \mathrm{mg} \text {; biotin, } \\
100 \mathrm{mg} \text {; folic acid, } 1 \mathrm{~g} \text {; choline chloride, } 250 \mathrm{~g} \text {; Antioxidant } 1,000 \mathrm{mg} \text {. } \\
{ }^{2} \text { Mineral premix contains followings in } 2.5 \mathrm{~kg} \text { : manganese, } 99,200 \mathrm{mg} \text {; } \\
\text { zinc, } 84,700 \mathrm{mg} \text {; iron, } 50,000 \mathrm{mg} \text {; copper, } 10,000 \mathrm{mg} \text {; Iodine } 990 \mathrm{mg} \text {; } \\
\text { selenium } 200 \mathrm{mg} \text {. }\end{array}$} \\
\hline
\end{tabular}

min to determine plasma antibody titers against Newcastle and infectious bronchitis disease viruses. Antibody titers against Newcastle disease virus were determined by haemagglutination inhibition (HI) test and were expressed as the logarithm base 2. Antibody titers against infectious bronchitis disease virus were determined by enzyme linked immunosorbent assay (ELISA) (IDEXX Inc., Westbrook, ME 04092, USA).

Blood smears were prepared using May-GreenwaldGiemsa stain and heterophil to lymphocyte ratios were based on a total of 100 cells (Gross and Siegel, 1983).

Plasma cortisol concentration measured by cortisol Elisa kit (RE52061 Westbrook, ME, USA). The result was monitored as OD at $450 \mathrm{~nm}$ and cortisol concentrations ( $\mathrm{mg} / \mathrm{ml}$ serum) were calculated from a standard curve as suggested by the company. Two birds from each replicate were slaughtered on day 42 and lymphoid organs such as spleen and Bursa of Fabricius were collected, weighed and expressed as a percentage of live body weight.

Data were analyzed by analysis of variance procedures appropriate for a completely randomized design using the GLM procedures of SAS (2002). Significant differences $(\mathrm{p}<0.05)$ among treatment means were determined using Duncan's new multiple range test.

\section{RESULTS AND DISCUSSION}

The effects of supplemental $\mathrm{Cr}$ on plasma cortisol levels, antibody titers against Newcastle and infectious bronchitis virus are shown in Table 2. Antibody titers against NDV and IBV at 21 and 42 days of age in broiler fed supplemental $\mathrm{Cr}$ were higher than in broiler chickens fed control diets $(p<0.05)$. Elevated antibody titers against NDV were reported in broiler chickens under heat stress with supplement of 2 or $10 \mathrm{ppm} \mathrm{Cr}$, either in the form of $\mathrm{CrCl}_{3}$ or yeast (Guo et al., 1999). Lee et al. (2003) reported that antibody titers against NDV was improved in broiler chickens fed $400 \mathrm{ppb} \mathrm{Cr}$ picolinate. Improved immune responses against virulent antigen were also reported in weanling pigs (Lee et al., 1997) with a dietary $\mathrm{Cr}$ supplement. CPC in broiler chickens fed $\mathrm{Cr}$ supplementation was lower than chickens fed a control diet. These results are in agreement with most experiments involving supplemental $\mathrm{Cr}$. A reduction in CPC of heatstressed broilers fed $\mathrm{Cr}$ picolinate was reported by Sahin et al. (2002). Chang and Mowat (1992) observed CPC decreased in stressed steers supplemented with $\mathrm{Cr}$ from high- $\mathrm{Cr}$ yeast. However, there are also a number of reports of no effect of $\mathrm{Cr}$ supplementation on serum cortisol levels (Kegley and Spears, 1995; Pollard et al., 2002).

Various stressors, including cold exposure (Sasaki and Weekes, 1986), short exposure to heat (Christison and Johnson, 1972), isolation (Hashizume et al., 1994), and 
Table 2. Effect of chromium supplementation on antibody titer against Newcastle and infectious bronchitis virus and cortisol levels at different ages of broiler

\begin{tabular}{|c|c|c|c|c|c|}
\hline Item & Control & $200 \mathrm{ppb} \mathrm{Cr}$ & $400 \mathrm{ppb} \mathrm{Cr}$ & $800 \mathrm{ppb} \mathrm{Cr}$ & SEM \\
\hline \multicolumn{6}{|c|}{ Newcastle titer $(\log , 2)$} \\
\hline 21 days & $1.91^{\mathrm{b}}$ & $2.08^{\mathrm{b}}$ & $2.41^{\mathrm{ab}}$ & $2.75^{\mathrm{a}}$ & 0.189 \\
\hline 42 days & $3.08^{\mathrm{c}}$ & $3.5^{\mathrm{bc}}$ & $4^{\mathrm{ab}}$ & $4.5^{\mathrm{a}}$ & 0.278 \\
\hline \multicolumn{6}{|c|}{ Infectious bronchitis titer (ELISA titer) } \\
\hline 21 days & $1,031.3^{\mathrm{b}}$ & $1,066.3^{\mathrm{b}}$ & $1,256.4^{\mathrm{ab}}$ & $1,400.1^{\mathrm{a}}$ & 97.2 \\
\hline 42 days & $2,871.2$ & $3,155.5$ & $3,447.2$ & $3,841.4$ & 308 \\
\hline \multicolumn{6}{|c|}{ Cortisol (ng/ml) } \\
\hline 21 days & $9.62^{\mathrm{a}}$ & $8.3^{\mathrm{b}}$ & $7.96^{\mathrm{b}}$ & $7.73^{\mathrm{b}}$ & 0.352 \\
\hline 42 days & $10.42^{\mathrm{a}}$ & $9.65^{\mathrm{ab}}$ & $9.22^{\mathrm{b}}$ & $8.78^{\mathrm{b}}$ & 0.313 \\
\hline
\end{tabular}

$\overline{a, b, c}$ Means within the same row without common superscripts differ significantly $(\mathrm{p}<0.05)$.

transportation (Arave et al., 1988) increase plasma cortisol. High concentrations of $\mathrm{Cr}$ from CrPic can directly inhibit cortisol secretion in an agonist-stimulated adrenocortical cell line (Kim et al., 2006). Zulkifli et al. (2000) reported antibody production in young broiler chickens was decreased in HS condition. This reduction could be indirectly due to an increase in inflammatory cytokines under stress, which stimulates the hypothalamic production of corticotrophin releasing factor (Ogle et al., 1997). Corticotrophin releasing factor is known to increase adrenocorticotropic hormone from the pituitary; adrenocorticotropic hormone then stimulates corticosterone production from the adrenal gland and corticosterone inhibits antibody production (Gross, 1992).

In this study, the increases in lymphocyte count and consequently decrease in heterophil to lymphocyte ratios in broiler chickens fed $800 \mathrm{ppb} \mathrm{Cr}$ were observed at 21 and 42 d (Table 3). The heterophil to lymphocyte ratio has been accepted as a reliable index for determining stress in poultry (Gross and Siegel, 1983; McFarlane and Curtis, 1989). It has also been found that exposure of birds to HS results in an increase in the heterophil to lymphocyte ratio (Altan et al., 2003; Zulkifli et al., 2003). Gross and Siegel (1983) found that the number of heterophils increased in the blood of corticosterone fed chickens. The increases in lymphocyte counts and decreases in heterophil to lymphocyte ratios by Cr supplementation in heat stressed chickens in the present study may be attributed to decreased glucocorticoid secretion.

The exact mechanism by which $\mathrm{Cr}$ enhances the immune system is not known. However, one of the consistent results of the studies was that $\mathrm{Cr}$ reduced plasma cortisol levels. Cortisol, the most important glucocorticoid, has been found to be immunosuppressive, inhibiting the production and actions of antibodies, lymphocyte function, and leucocyte population (Roth and Kaeberle, 1982; Munck et al., 1984).

Supplementation with CrMet had no significant effect on lymphoid organs of broilers (Table 4). However, all organ weights were significantly reduced when birds were

Table 3. Effect of chromium supplementation on heterophil and lymphocyte count and ratio (H/L)

\begin{tabular}{|c|c|c|c|c|c|}
\hline Item & Control & $200 \mathrm{ppb} \mathrm{Cr}$ & $400 \mathrm{ppb} \mathrm{Cr}$ & $800 \mathrm{ppb} \mathrm{Cr}$ & SEM \\
\hline \multicolumn{6}{|l|}{21 days } \\
\hline Heterophil \% & 38.41 & 36.25 & 33.33 & 33.91 & 2.23 \\
\hline Lymphocyte \% & $60.08^{\mathrm{b}}$ & $62.5^{\mathrm{ab}}$ & $65.41^{\mathrm{a}}$ & $67.5^{\mathrm{a}}$ & 1.76 \\
\hline $\mathrm{H} / \mathrm{L}$ & $0.66^{\mathrm{a}}$ & $0.58^{\mathrm{ab}}$ & $0.51^{\mathrm{b}}$ & $0.49^{\mathrm{b}}$ & 0.047 \\
\hline \multicolumn{6}{|l|}{42 days } \\
\hline Heterophil \% & $38.91^{\mathrm{b}}$ & $38.16^{\mathrm{b}}$ & $37.58^{\mathrm{b}}$ & $26.5^{\mathrm{a}}$ & 2.09 \\
\hline Lymphocyte \% & $52.66^{\mathrm{b}}$ & $54.25^{\mathrm{b}}$ & $53.91^{\mathrm{b}}$ & $68.08^{\mathrm{a}}$ & 1.67 \\
\hline $\mathrm{H} / \mathrm{L}$ & $0.74^{\mathrm{a}}$ & $0.70^{\mathrm{a}}$ & $0.70^{\mathrm{a}}$ & $0.38^{\mathrm{b}}$ & 0.042 \\
\hline
\end{tabular}

${ }^{\mathrm{a}-\mathrm{b}}$ Means within the same row without common superscripts differ significantly $(\mathrm{p}<0.05)$.

Table 4. Effect of chromium supplementation on lymphoid organ weight (percentage of live body weight) at 42 days of age

\begin{tabular}{lccccc}
\hline Lymphoid organ & Control & $200 \mathrm{ppb} \mathrm{Cr}$ & $400 \mathrm{ppb}$ Cr & $800 \mathrm{ppb} \mathrm{Cr}$ & SEM \\
\hline Bursa of fabricius & 0.193 & 0.183 & 0.191 & 0.178 & 0.021 \\
Spleen & 0.133 & 0.118 & 0.110 & 0.128 & 0.019 \\
\hline
\end{tabular}

${ }^{\mathrm{a}-\mathrm{b}}$ Means within the same row without common superscripts differ significantly $(\mathrm{p}<0.05)$. 
exposed to HS $(\mathrm{p}<0.05)$. Toghyani et al. (2007) observed that supplementation with different levels of Cr-picolinate in the diet of heat-stressed broilers had no effect on lymphoid organs. Bartlett and Smith (2003) suggest that the decrease in lymphoid organ weights could have been a result of the reduction in feed intake, thereby providing fewer nutrients for proper development of these organs under HS conditions.

Overall, it appears that dietary CrMet supplementation at level of $800 \mathrm{ppb}$ can improve some immune responses of broiler under HS condition. More extensive research is needed to determine the effect of Cr-Methionine on growth performance and immune response in broilers under varying rearing conditions.

\section{REFERENCES}

Altan, O., A. Pabuccuoglu, A. Altan, S. Konyalioglu and H. Bayraktar. 2003. Effect of heat stress on oxidative stress, lipid peroxidation and some stress parameters in broilers. Br. Poult. Sci. 44:545-550.

Anderson, R. A. 1987. Chromium. In: Trace Elements in Human and Animal Nutrition. pp. 225_244 Academic Press. New York.

Anderson, R. A., N. A. Bryden, M. M. Polansky and P. A. Deuster. 1988. Exercise effects on chromium excretion of trained and untrained men consuming a constant diet. J. Appl. Physiol. 64: 249.

Arave, C. W., K. Warnick, J. L. Walters and D. Purcell. 1988. Stress of transporting cows as measured by serum glucocorticoids and milk production. J. Dairy Sci. 71(Suppl. 1): 214 (abstract).

Bartlett, J. R. and M. O. Smith. 2003. Effects of different levels of zinc on the performance and immunocompetence of broilers under heat stress. Poult. Sci. 82:1580-1588.

Burton, J. L., B. A. Mallard and D. N. Mowat. 1993. Effects of supplemental chromium on immune responses of periparturient and early lactation dairy cows. J. Anim. Sci. 71: 1532-1539.

Borel, J. S., T. C. Majerus, M. M. Polansky, P. B. Mozer and R. A. Anderson. 1984. Chromium intake and urinary $\mathrm{Cr}$ excretion of trauma patients. Biol. Trace Elem. Res. 6:317-326.

Chang, X. and D. N. Mowat. 1992. Supplemental chromium for stressed and growing feeder calves. J. Anim. Sci. 70:559.

Christison, G. I. and H. D. Johnson. 1972. Cortisol turnover in heat-stressed cows. J. Anim. Sci. 35:1005-1010.

Guo, Y. L., X. G. Luo, Z. L. Hao, B. Liu, J. L. Chen, F. S. Gao and S. X. Yu. 1999. Effect of chromium on growth performance, serum biochemical traits, immune function and carcass quality of broiler chickens. Scientia Agriculture Sinica 32:79-86.

Gross, W. B. 1992. Effect of short-term exposure of chickens to corticosterone on resistance to challenge exposure with Escherichia coli and antibody response to sheep erythrocytes. Am. J. Vet. Res. 53:291-293.

Gross, W. B. and P. S. Sigel. 1983. Evaluation of heterophil to lymphocyte ratio as a measure of stress in chickens. Avian Dis. 27:972-979.
Giri, J., K. Usha and T. Sunita. 1990. Evaluation of the selenium and chromium content of plants foods. Plant Foods Hum. Nutr. 40:49-59.

Hashizume, T., S. A. Haglof and P. V. Malven. 1994. Intracerebral methionine-enkephalin, serum cortisol, and serum endorphin during acute exposure of sheep to physical or isolation stress. J. Anim. Sci. 72:1893-1902.

Kim, B. G., B. A. Adams, B. A. Jackson and M. D. Lindemann. 2006. Effect of chromium(III) picolinate on cortisol and DEHAs secretion in H295R human adrenocortical cells. FASEB J. 20:142.2 (abstract).

Kegley, E. B. and J. W. Spears. 1995. Immune response, glucose metabolism, and performance of stressed feeder calves fed inorganic or organic chromium. J. Anim. Sci. 73:2721-2726.

Luo, X., Y. L. Guo, B. Liu, Z. L. Hao, J. L. Chen, F. S. Gao and S. X. Yu. 1999. Effect of dietary chromium on growth, serum biochemical traits and immune responses of broiler chicks during 0-3 weeks of age. Acta Veterinary et Zootechnica Sinica, 30:481-489.

Lee, D. N., F. Y. Wu, Y. H. Cheng, R. S. Lin and P. C. Wu. 2003. Effect of dietary chromium picolinate supplementation on growth performance and immune responses of broilers. AsianAust. J. Anim. Sci. 16:227-233.

Lee, D. N., H. T. Yen, T. F. Shen and B. J. Chen. 1997. The effects of chromium picolinate supplementation on growth performance and immunity response of weanling pigs. Journal of Chinese Society of Animal Science 26:373386.

McFarlane, J. M. and S. E. Curtis. 1989. Multiple concurrent stressors in chicks. 3. Effects on plasma corticosterone and the heterophil to lymphocyte ratio. Poult. Sci. 68:522-527.

Moonsie-Shageer, S. and D. N. Mowat. 1993. Effect of level of supplemental chromium on performance, serum constituents, and immune status of stressed feeder calves. J. Anim. Sci. 71: 232-238.

Munck, A., P. M. Guyre and N. J. Holbrook. 1984. Physiological functions of glucocorticoids in stress and their relation to pharmacological actions. Endocrinol. Rev. 5:25-44.

Mertz, W. 1993. Chromium in human nutrition: a review. J. Nutr. 123:626-633.

National Research Council. 1994. Nutrient requirements of poultry. $9^{\text {th }}$ rev. ed. National Academy Press, Washington, DC.

National Research Council. 1997. The role of chromium in animal nutrition. National Academy Press, Washington, DC.

Ogle, C. K., J. F. Valente, X. Guo, B. G. Li, J. D. Ogle and J. W. Alexander. 1997. Thermal injury induces the development of inflammatory macrophages from nonadherent bone marrow cells. Inflammation 21:569-582.

Pollard, G. V., C. R. Richardson and T. P. Karnezos. 2002. Effects of supplemental organic chromium on growth, feed efficiency and carcass characteristics of feedlot steers. Anim. Feed Sci. Technol. 98:121-128.

Pekarek, R. S., E. C. Hauser, E. J. Rayfield, R. W. Wannemacher and W. R. Beisel. 1975. Relationship between serum chromium concentrations and glucose utilization in normal and infected subjects. Diabetes 24:350.

Roth, J. A. and M. L. Kaeberle. 1982. The effect of glucocorticoids on the bovine immune system. Journal of American Veterinary Medicine Association, 180:230-235. SAS 
Institute. 2003. SAS 9.1. SAS Inst. Inc., Cary, NC.

Sahin, K., N. Sahin, M. Onderci, F. Gursu and G. Cikim. 2002.

Optimal dietary concentration of chromium for alleviating the effect of heat stress on growth, carcass qualities and some serum metabolites of broiler chickens. Biol. Trace Elem. Res. 89:53-64.

Sasaki, Y. and T. E. C. Weekes. 1986. Metabolic response to cold. In: Control of Digestion and Metabolism in uminants (Ed. L. P. Milligan, W. L. Grovum And A. Dobson). Prentice-Hall, Englewood Cliffs, NJ, p. 326.

Thaxton, P., C. R. Sadler and B. Glick. 1968. Immune response of chickens following heat exposure or injection with ACTH. Poult. Sci. 47:264-266.
Thaxton, P. and H. S. Siegel. 1972. Depression of secondary immunity by high environmental temperature. Poult. Sci. 51:1519-1526.

Toghyani, M., S. Zarkesh, M. Shivazad and A. Gheisari. 2007. Immune response of broiler chicks fed chromium picolinate in heat stress condition. J. Poult. Sci. 44:330-334.

Zulkifli, I., M. T. Che Norma, D. A. Israf and A. R. Omar. 2000. The effect of early age feed restriction on subsequent response to high environmental temperatures in female broiler chickens. Poult. Sci. 79:1401-1407.

Zulkifli, I., P. K. Liewa, D. A. Israf, A. R. Omar and M. Hair-Bejo. 2003. Effects of early age feed restriction and heat conditioning on heterophil to lymphocyte ratios, heat shock protein 70 expression and body temperature of heat-stressed broiler chickens. J. Therm. Biol. 28:217-222. 